\title{
Development of an In Vitro-In Vivo Correlation for Sitagliptin and Metformin Prolonged-release Tablet Formulations
}

\author{
Sitaglipin ve Metformin Uzatılmış Salınımlı Tablet Formülasyonları İçin \\ In Vitro-In Vivo Korelasyon Geliştirme
}

\author{
(D) Rajkumar BODDU1, (D) Harikiran Chary VADLA1, (D) Vamshi Ramana PRATHAP1, (D) Umamaheshwar KOTHAMASU2, \\ (D) Balaramesha Chary RALLABANDI1, (D) Ramesh GANNU1* \\ 1Product Development, AET Laboratories Pvt. Ltd, Sangareddy District, Telangana State, India \\ 2Clinical Department, AET Laboratories Pvt. Ltd, Sangareddy District, Telangana State, India
}

\begin{abstract}
Objectives: The objective of this study was to establish and validate an in vitro-in vivo correlation (IVIVC). To investigate the safety of a fixed-dose combination (FDC) versus the reference formulations (Januvia ${ }^{\circledR} 100$ mg Filmtabletten co-administered with Glucophage ${ }^{\circledR}$ SR 1000 mg prolongedrelease tablets), a bioequivalence study was conducted in the fasted and fed states, and the data generated were used to establish the correlation. Materials and Methods: The formulations used in the bioequivalence study were a FDC (sitagliptin hydrochloride equivalent to $100 \mathrm{mg}$ of sitagliptin and metformin hydrochloride $1000 \mathrm{mg}$ prolonged release) and Januvia ${ }^{\circledR} 100 \mathrm{mg}$ co-administered with Glucophage ${ }^{\circledR}$ SR 1000 mg. The plasma profiles from the bioequivalence study and respective dissolution data were then utilized to establish "level A" IVIVC. The procedure comprises pharmacokinetic modeling to derive the empirical constants for further use in deconvolution and convolution procedures. Levy plots were constructed to understand the relationship between in vitro and in vivo properties. The internal and external predictabilities were evaluated by comparing the predicted pharmacokinetics with the observed values from the bioequivalence study.

Results: The formulations showed approximately $91 \%-95 \%$ and $89 \%-91 \%$ dissolution, respectively in fasted and fed-state dissolution media for sitagliptin. The dissolution of metformin was $96 \%-98 \%$ and $89 \%-95 \%$, respectively, in fasted and fed-state media. The regression coefficients of all the Levy plots were more than 0.900 , indicating a linear correlation between in vitro release and in vivo parameters. The prediction error value of internal and external predictabilities was below 10 and met the US Food and Drug Administration criteria. Therefore, it can be stated that the correlation models are validated and can be used for predictions and to setting the dissolution specifications. The safety and tolerability of the FDC was found to be superior to those of the reference formulations, as fewer adverse events occurred following administration of the FDC.

Conclusion: Correlation models can be useful for the prediction of FDCs during the management life cycle of the product. The models can also serve as a surrogate for in vivo studies. The FDC was tolerable, and the adverse events were mild and similar to those observed with the reference products. Therefore, the FDC is safe for use in human subjects.
\end{abstract}

Key words: IVIVC, level A correlation, Levy plot, sitagliptin hydrochloride, metformin hydrochloride

Öz

Amaç: Bu çalıșmanın amacı sabit doz kombinasyonunun (FDC) güvenliliğini araștırmak için referans formülasyonlara (Januvia ${ }^{\circledR} 100$ mg Filmtabletten ie birlikte uygulanan Glucophage ${ }^{\circledR}$ SR 1000 mg uzatılmış salınımlı tablet) karșı in vitro-in vivo korelasyonu (IVIVC) kurmak ve valide etmektir. Bu nedenle, aç ve tok durumlarda bir biyoeşdeğerlik çalışması yapılmış ve elde edilen veriler korelasyon kurmak için kullanılmıştır.

Gereç ve Yöntemler: Biyoeșdeğerlik çalışmalarında kullanılan formülasyonlar bir FDC (100 mg sitaglipine eș staglipin hidroklorür ve uzun salınımlı metformin hidroklorür 1000 mg) idi. Biyoeşdeğerlik çalışmasının plazma profilleri ve takip eden dissolüsyon verileri "düzey A" IVIVC kurmak için kullanılmıştır. Bu prosedür, dekonvülüsyon ve konvülüsyon prosedürlerinde kullanılmak üzere ampirik sabiteleri derive etmek için kullanılan bir farmakokinetik modellemeden olușmaktadır. In vitro ve in vivo özellikler arasındaki ilișkiyi anlamak için için levy grafikleri düzenlenmiștir. İç ve dıș tahmin edilebilirlikler biyoeșdeğerlik çalışmasından elde edilen tahmini gözlemlenen değerler ile farmakokinetikleri karşılaştırarak değerlendirilmiştir. 
Bulgular: Sitaglipin formülasyonları aç ve tokluk durumları için dissolüsyon medyasında sırasıyla yaklaşık \%91-\%95 ve \%89-\%91 dissolüsyon göstermiștir. Metforminin dissolüsyonu aç ve tokluk durumları için dissolüsyon medyasında sırasıyla yaklaşık \%96-\%98 ve \%89-\%95 idi. Tüm levy grafiklerinin regresyon katsayıları 0,900'ün üzerindeydi ki bu in vitro salım ile in vivo parametreler arasında doğrusal bir korelasyon varlığını göstermekteydi. İç ve dış tahmin edilebilirlikler için tahmini hata değeri 10'un altında idi ve Amerikan Gıda ve İlaç Dairesi kriterlerine uymaktaydı. Bu nedenle, korelasyon modellerinin valide olduğu ifade edilebilir ve tahmin edilebilirlikler ve dissolüsyon spesifikasyonlarını belirlemek için kullanılabileceği söylenebilir. FDC'nin güvenliliği ve tolere edilebilirliği referans formülasyonlardan daha üstün bulunmuştur; zira FDC'nin uygulanmasını takiben daha az sayıda advers etkiler görülmüștür.

Sonuç: FDC'lerin tahmininin korelasyon modelleri için ürünün yaşam döngüsünün idare edilmesinde faydalı olabileceği söylenebilir. Bu modeller in vivo çalışmalar için yedek modeller olarak da işlev görebilir. FDC tolere edebilir özelliktedir ve advers etkileri hafiftir ve referans ürünlerle gözlenen etkilere benzerdir. Bu nedenle, FDC'nin insanlarda kullanımı güvenilirdir.

Anahtar kelimeler: IVIVC, A düzeyi korelasyon, levy plotu, sitagliptin hidroklorür, metformin hidroklorür

\section{INTRODUCTION}

Sitagliptin, a dipeptidyl peptidase 4 inhibitor, is indicated for hyperglycemia.' Sitagliptin exerts its action by prolonging the action of glucagon-like peptide-1 (GLP-1) and glucosedependent insulinotropic polypeptide but facilitates insulin production and reduces the secretion of glucagon, which in turn decreases hepatic glucose overproduction. ${ }^{2}$ Food does not show a significant influence on the pharmacokinetics of sitagliptin; hence, sitagliptin can be taken without regards to food. Metformin is prescribed as a first-line therapy in type2 diabetes. ${ }^{3}$ Metformin exerts a glucose-lowering effect (i) via inhibition of gluconeogenesis in the liver, (ii) by delaying the action of glucagon, (iii) by facilitating the action of insulin, and (iv) by delaying glucose absorption from the intestine. ${ }^{4.5}$ As per the biopharmaceutical classification system (BCS), both sitagliptin and metformin possess high solubility and poor permeability; therefore, both drugs belong to BCS class III. ${ }^{6.7}$

A fixed-dose combination (FDC) comprising sitagliptin hydrochloride equivalent to sitagliptin $100 \mathrm{mg}$ as an immediaterelease form and metformin hydrochloride1000 $\mathrm{mg}$ as a prolonged-release form was developed. FDCs offer numerous merits, ${ }^{8}$ in comparison with individual drug products, including the simplicity of dosage forms in terms of the dosing schedule. This leads to improved patient compliance and results in an overall better treatment outcome. This aspect is especially important in elderly patients or those suffering from multiple disorders. The in vivo behavior of Januvia ${ }^{\circledR}$, Glucophage ${ }^{\circledR} 1000$ $\mathrm{mg} \mathrm{SR}$, and the FDC were evaluated in a bioequivalence study including healthy subjects. ${ }^{9}$ The FDC was developed in order to avoid administration of two individual products for the routine treatment of type-2 diabetes mellitus. The formulations (FDC vs individual innovator products) as a part of development have been evaluated and their safety, bioequivalence, and tolerability proved in human volunteers in the fasted and fed states. ${ }^{9}$

In the management life cycle of formulations, the need always arises for changes in parameters, such as the composition, process, equipment, scale-up or scale-down, or the manufacturing site. In certain instances, post-approval changes may trigger the conduct and reporting of further bioequivalence testing for the modified and marketed formulations. ${ }^{10}$ Furthermore, the availability of an in vitro-in vivo correlation (IVIVC) can simulate and predict plasma profiles and can serve as a surrogate for in vivo studies. Therefore, an IVIVC was developed and validated for predictability using bioequivalence data collected in the fasted and fed states. The present paper describes the developmental aspects of the IVIVC and those of internal and external validation. Correlation models can be useful for the prediction of FDCs during the management life cycle of the product.

\section{MATERIALS AND METHODS}

\section{Formulations tested}

The formulations evaluated for bioequivalence are shown in Table 1. A FDC (composition is not disclosed) containing sitagliptin hydrochloride equivalent to sitagliptin $100 \mathrm{mg}$ and metformin hydrochloride $1000 \mathrm{mg}$ prolonged-release tablets (AET Laboratories Pvt. Ltd, India) was used as the test formulation. The in vivo behavior of the test formulation as a FDC was compared with those of individual reference formulations, namely Januvia ${ }^{\circledR} 100$ mg Filmtabletten (lot no. 362117, marketed by Merck Sharp \& Dohme Ltd., UK) and Glucophage ${ }^{\circledR}$ SR 1000

Table 1. Scheme of the clinical study

\begin{tabular}{|c|c|c|c|c|}
\hline \multirow{2}{*}{ Period } & \multicolumn{2}{|l|}{ Cohort $1(n=12)$} & \multicolumn{2}{|l|}{ Cohort $2(n=12)$} \\
\hline & Group $1(n=6)$ & Group $2(n=6)$ & Group $1(n=6)$ & Group $2(n=6)$ \\
\hline 1 & ${ }^{\star} \mathrm{FDC}$ & $\begin{array}{l}\text { \#Januvia }{ }^{\circledR} 100 \mathrm{mg} \text { and Glucophage }{ }^{\circledR} \mathrm{SR} \\
1000 \mathrm{mg}\end{array}$ & ${ }^{*} \mathrm{FDC}$ & $\begin{array}{l}{ }^{\text { Januvia }}{ }^{\circledR} 100 \text { mg and } \\
\text { Glucophage }{ }^{\circledR} \text { SR } 1000 \\
\text { mg }\end{array}$ \\
\hline 2 & $\begin{array}{l}\text { \#Januvia }{ }^{\circledR} 100 \mathrm{mg} \text { and } \\
\text { Glucophage }^{\circledR} \mathrm{SR} 1000 \mathrm{mg}\end{array}$ & ${ }^{*} \mathrm{FDC}$ & $\begin{array}{l}\text { \#Januvia }{ }^{\circledR} 100 \text { mg and } \\
\text { Glucophage }^{\circledR} \text { SR } 1000 \text { mg }\end{array}$ & ${ }^{*} \mathrm{FDC}$ \\
\hline
\end{tabular}

*: FDC comprising sitagliptin hydrochloride, equivalent to $100 \mathrm{mg}$ sitagliptin and metformin hydrochloride $1000 \mathrm{mg}$ and is manufactured by AET Laboratories Pvt Ltd., India. \#: Originators comprises of sitagliptin phosphate monohydrate, equivalent to $100 \mathrm{mg}$ sitagliptin (Januvia ${ }^{\circledR} 100 \mathrm{mg}$ ) and metformin hydrochloride $1000 \mathrm{mg}$ as prolonged release (Glucophage ${ }^{\circledR}$ SR $1000 \mathrm{mg}$ ). FDC: Fixed-dose combination 
mg prolonged-release tablets (lot no. GXC15222, marketed by Merck Serono Ltd., UK). In cohort 1, the study was conducted under fasting conditions and in cohort 2 , in the fed state. ${ }^{9}$

\section{Dissolution method}

The in vitro release of sitagliptin and metformin from FDC, Januvia $^{\circledR} 100$ mg Filmtabletten and Glucophage ${ }^{\circledR}$ SR 1000 mg prolonged-release tablets was performed using a USP I (basket) apparatus (Electrolab, Mumbai, India). Individual tablets were placed in dissolution vessels containing $900 \mathrm{~mL}$ of dissolution media. Phosphate buffer, pH 6.8 and acetate buffer, $\mathrm{pH} 5.5$ were selected as the dissolution media for fasted- and fed-state conditions, respectively. The $\mathrm{pH}$ of the dissolution media was based on the $\mathrm{pH}$ of the gastrointestinal (Gl) tract in the fasted and fed states. The preprandial $\mathrm{Gl} \mathrm{pH}$ was 1 to 7.5, and the postprandial $\mathrm{pH}$ was 2.7-6.4 (stomach) and 4-8 (intestine).11-13 Due to the high solubility and $\mathrm{pH}$-independent soluble nature of the molecules, aqueous buffers at one $\mathrm{pH}$ for each condition was selected. The study was conducted at a rotational speed of $100 \mathrm{rpm}$. The samples were collected for up to $60 \mathrm{~min}$ for sitagliptin and $12 \mathrm{~h}$ for metformin and replenished with the respective fresh media. The drug released from the samples was analyzed using a high-performance liquid chromatography (HPLC) system (Waters, Singapore) equipped with a quaternary pump, ultraviolet-visible spectrophotometric detector (Perkin Elmer, Lambda 25, Massachusetts, USA), and $\mathrm{C}_{8}$ column $(100 \times 2.1 \mathrm{~mm}$, particle size of $1.7 \mu \mathrm{m})$. The mobile phase consisted of acetonitrile, $10 \mathrm{mM}$ potassium dihydrogen phosphate buffer, and $2 \mathrm{mM}$ sodium hexane-1-sulfonate. The $\mathrm{pH}$ of the mobile phase was adjusted to 5.5 using phosphoric acid. The flow rate was $1 \mathrm{~mL} \mathrm{~min}{ }^{-1}$, and the detection wavelength was $210 \mathrm{~nm} .{ }^{14}$ The precision and accuracy of the chromatographic method were checked and were found to be within the required limits (coefficient of variation $<15 \%$ ). The dissolution profiles were subjected to similarity assessment in accordance with the guidelines. $^{10}$

\section{In vivo characterization}

\section{Subjects and study approval}

A mixed population comprising 24 healthy subjects (including 9 male and 15 female subjects) after screening were enrolled in the bioequivalence study (Table 1). The subjects were grouped in two cohorts, each consisting of 12 subjects. Subjects were included in accordance with the guidelines, ${ }^{15}$ and the inclusion criteria were age $\geq 18$ years and body mass index $18.5-30 \mathrm{~kg} / \mathrm{m}^{2}$. The study protocol was approved (refer to letter number: 429) by the National Ethics Committee for Drugs Clinical Trials and to the Medicines and Medical Devices Agency Chisinau, The Moldavian Republic (date: 27.12.2017, no: 429). The study was conducted $^{9}$ in agreement with the Declaration of Helsinki (1964 and subsequent amendments), ICH-good clinical practice (GCP) R2, ${ }^{16}$ EEC rules and in accordance with GCP for the conduct of clinical studies. The subjects' medical histories were recorded by the clinical investigator. A medical examination was conducted to record systolic arterial pressure (SAP), diastolic arterial pressure (DAP), heart rate, electrocardiogram (ECG), body temperature, and respiratory frequency. Biological samples (urine and blood) were collected for analysis from a clinical chemistry perspective.

\section{Study design}

The study was performed as an open label, two-period, twoway crossover, randomized controlled, single-dose comparative bioequivalence study between the FDC and reference formulations in healthy subjects with a wash-out period of 14 days between periods. Blood samples were collected before the study drug administration and at $0.33,0.67,1.00,1.33,1.67$, $2.00,2.33,2.67,3.00,3.33,3.67,4.00,4.33,4.67,5.00,5.33$, $5.67,6.00,7.00,8.00,9.00,10.00,12.00,16.00,24.00,48.00$ $72.00,96.00$, and 120.00 hours post dose. The blood samples were centrifuged for 10 minutes at $4^{\circ} \mathrm{C}$ nominal with a force of $1500( \pm 5) \mathrm{g}$. After centrifugation, the plasma was separated into two aliquots and stored at $-20^{\circ} \mathrm{C}$ until sample analysis.

\section{Bioanalytical procedure: estimation of analytes from plasma}

Sample analysis and processing were performed by the Analytical Laboratory of 3S-Pharmacological Consultation \& Research GmbH (Bucharest, Romania). The concentrations of sitagliptin and metformin were measured by reversed-phase HPLC coupled to a tandem mass spectrometry detector (LC/ MS/MS). The separations were performed isocratically on a reversed-phase column (Agilent Zorbax 300-SCX, 2.1x50 $\mathrm{mm}, 5 \mu \mathrm{m}$ ) with a flow rate of $1.00 \mathrm{~mL} / \mathrm{min}$. The mobile phase consisted of methanol and $75 \mathrm{mM}$ ammonium acetate buffer (80:20). The internal standards used were sitagliptin-D4 and metformin-D6. Detection was carried out by triple quadrupole MS/MS with an AB-Sciex model, API 5500 QTRAP, equipped with an atmospheric pressure ionization interface (Model, Turbo Spray). The precursor and product ions used for detection were 408,123/235,100 for sitagliptin, 412,088/239,100 for sitagliptin-D4, 129,975/71,200 for metformin, and $136,026 / 60,000$ for metformin-D6.The analytical method was validated in accordance with GLP principles, US Food and Drug Administration (FDA) rules, ${ }^{17}$ European Medicines Agency (EMA) guidelines, ${ }^{18}$ and the current Romanian GLP guidance. The method was developed and validated in the concentration range of $1.0-800 \mathrm{ng} / \mathrm{mL}$ and $5.0-4000 \mathrm{ng} / \mathrm{mL}$, respectively, for sitagliptin and metformin. During validation, the stability of the internal standard working solution (up to 16 hours at room temperature), system suitability test solution stability (up to 1 week when stored below $-20^{\circ} \mathrm{C}$ ), spiked plasma sample stability (up to 6 hours at room temperature, up to 1 week at $-5^{\circ} \mathrm{C}$, up to 11.5 months below $-20^{\circ} \mathrm{C}$, up to 1 week below $-70^{\circ} \mathrm{C}$ ), freezethaw stability (up to 5 cycles), and stability of spiked plasma sample extract (up to 48 hours at $10^{\circ} \mathrm{C}$ ) were evaluated.

\section{Sample preparation}

An aliquot of $0.150 \mathrm{~mL}$ of plasma sample was transferred to $2 \mathrm{~mL}$ multi-well plates. Fifty microliters of working internal standard solution was added to the plasma sample and mixed for 3 minutes followed by addition of $0.800 \mathrm{~mL}$ of acetonitrile. The contents were mixed for 5 minutes and centrifuged for 5 minutes at $4000 \mathrm{rpm}\left(20^{\circ} \mathrm{C}\right.$, nominal). The supernatant was separated and diluted, and $20 \mu \mathrm{L}$ was injected in to HPLC. 


\section{Pharmacokinetic variables}

The pharmacokinetic parameters, peak drug concentration $\left(\mathrm{C}_{\max }\right)$ and area under the curve from time zero to time t $\left(A \cup \mathrm{C}_{0-\mathrm{t}}\right)$ as primary parameters and area under the curve from time zero to infinity $\left(A \cup C_{0-\operatorname{lnf}}\right.$ ) and time of the peak drug concentration $\left(T_{\text {max }}\right)$ as secondary parameters were calculated.

$c \delta(\mathrm{t})=\sum_{j=1}^{n} \mathrm{Aj} e^{-\alpha \mathrm{j} t}$

\section{Safety and tolerability}

The clinical safety of the formulations was assessed via medical history, clinical examination (physical and systemic examination), 12-lead ECG, and vital signs (blood pressure, heart rate, respiratory rate, and temperature), and biochemical parameters. The parameters were measured at the time of check-in to the study center and before treatment in each study period. Before dosing in each period at at follow-up, the subjects were asked about their health status and medication consumption. The SAP, DAP, heart rate, and body temperatures were measured before dosing and during the study for each period.

\section{Development of in vitro-in vivo correlation}

Phoenix ${ }^{\circledR}$ Version 8.1 software was used for the pharmacokinetic modeling, deconvolution, and convolution procedures. Pharmacokinetic modeling was performed in order to fit the best model by varying the parameters, e.g., with and without lag time and choosing one- or twocompartment models. Among the attempts, the one that yielded a high correlation coefficient was chosen for further consideration. Accordingly, the empirical constants ( $A$ and alpha) were chosen for the deconvolution and convolution procedures. " $\mathrm{A}$ " and "alpha" refer to the parameters of a poly exponential unit impulse response function of the form Where, " $\mathrm{N}$ " is the number of exponential terms, " $\mathrm{C} \delta$ " represents to concentration time course, and " $\mathrm{t}$ " stands for time.

The in vivo plasma concentrations versus time profiles were deconvolved to derive the fraction absorbed $\left(F_{a}\right)$. Then, the fraction of drug absorbed was correlated with the drug dissolved in order to construct a "levy" plot.

\section{Validation of the IVIVC}

The empirical constants were chosen for the convolution of dissolution profiles in order to derive the plasma-concentrationtime-profile. The simulated plasma profile was further subjected to the calculation of pharmacokinetics to compute $C_{\text {max' }}, A U C_{0-t^{\prime}}$ and $A \cup C_{0-\ln \text { f }^{\prime}}$ The prediction error (PE) was calculated for $\mathrm{C}_{\text {max' }}$ $A \cup C_{0-1,}$ and $A C_{0-1 n f}$ for each formulation and for each drug substance using the equation below:

$\mathrm{PE}=[$ (observed-predicted)/observed] $\times 100$

The predictability of the correlation model was evaluated using the internal and external predictabilities as per FDA guidance.19 For both internal and external validation, the mean PE was required and should be not more than $10 \%$ for $\mathrm{C}_{\text {max }}, \mathrm{AUC}_{0-\mathrm{t}^{\prime}}$ and $\mathrm{AUC}_{0-\ln }$.

No statistical methods were used for the data treatment.

\section{RESULTS}

In vitro release

\section{Sitagliptin}

The in vitro drug-release profiles of FDC and Januvia ${ }^{\circledR}$ using the selected method (USP 1, $100 \mathrm{rpm}$ at pH 6.8 and pH 5.5) are presented in Figure 1. The immediate-release form of sitagliptin showed approximately $91 \%-95 \%$ of dissolution in phosphate buffer $\mathrm{pH} 6.8$ and $89 \%-91 \%$ dissolution in acetate buffer at $\mathrm{pH}$ 5.5. Despite the differences in salt from Januvi ${ }^{\circledR}$ and FDC, the dissolution appeared to be complete and gradual. However, differences existed in the dissolution pattern. To check the impact of the difference in dissolution between the reference and test formulations, the similarity factor $\left(f_{2}\right)$ was assessed for the dissolution profiles. The $f_{2}$ values were found to be 54 for both fasted and fed-state dissolutions. An $f_{2}$ value greater than 50 is an indication of similarity. ${ }^{10}$

\section{Metformin}

The in vitro drug-release profiles of FDC and Glucophage ${ }^{\circledR} \mathrm{SR}$ $1000 \mathrm{mg}$ using the selected method (USP $1,100 \mathrm{rpm}$ at $\mathrm{pH} 6.8$ and $\mathrm{pH}$ 5.5) are presented in Figure 2. The prolonged-release form of metformin $\mathrm{HCl}$ showed approximately $96 \%-98 \%$ dissolution at $\mathrm{pH} 6.8$ and $89 \%-95 \%$ dissolution at $\mathrm{pH}$ 5.5. The dissolution profiles appear to be gradual and complete. The $f_{2}$ values were found to be 65 (at pH 6.8) and 55 (at pH 5.5), respectively, also an indication of the similarity of the dissolution profiles. ${ }^{10}$

\section{IVIVC model}

The plasma profiles of sitagliptin (Figure $3 \mathrm{~A}$ ) and metformin (Figure 3B) from the bioequivalence study were deconvoluted to derive the respective in vivo absorption profiles (Figure 4A, B). Levy plots were constructed to understand the relation

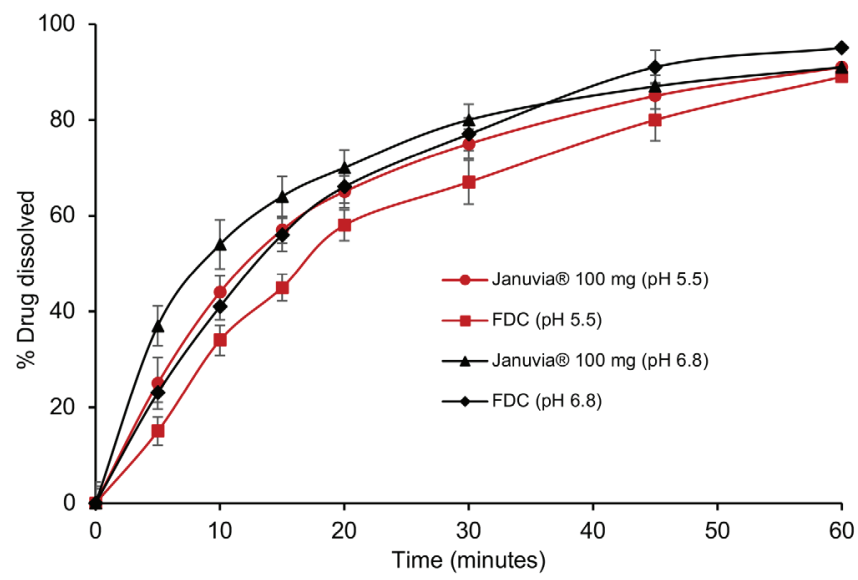

Figure 1. In vitro release of sitagliptin from FDC and Januvia ${ }^{\circledR} 100 \mathrm{mg}$ at $\mathrm{pH}$ 6.8 and $\mathrm{pH}$ 5.5. FDC contains sitagliptin $\mathrm{HCl}$, and Januvia ${ }^{\circledR} 100 \mathrm{mg}$ contains sitagliptin phosphate monohydrate equivalent to $100 \mathrm{mg}$ sitagliptin, respectively

FDC: Fixed-dose combination 
between the in vitro sitagliptin dissolved and in vivo sitagliptin absorbed (Figure 5A, B). Regression coefficients of 0.952 and 0.976 for Januvia ${ }^{\circledR}$ and FDC indicate that a good linear correlation existed between in vitro and in vivo parameters under fasting conditions. Similarly, the correlation coefficients were 0.996 and 0.963 , respectively, for Januvia ${ }^{\circledR}$ and FDC tested under fed conditions (Figure 5C, D). Despite the differences in the salts used in the formulations, the in vitro tool showed good discrimination. Hence, the employed dissolution method can be used for the characterization of formulations containing either of the salts.

The levy plots of metformin (Figure 6A, B) using the data obtained in the fasted state study showed a regression coefficient of 0.971 and 0.937 , respectively, for Glucophage ${ }^{\circledR} \mathrm{SR}$ $1000 \mathrm{mg}$ and FDC. The regression coefficients of fed-state data were 0.965 and 0.959, respectively, for Glucophage ${ }^{\circledR}$ SR 1000 $\mathrm{mg}$ and the FDC (Figure 6C, D). The results indicate that the

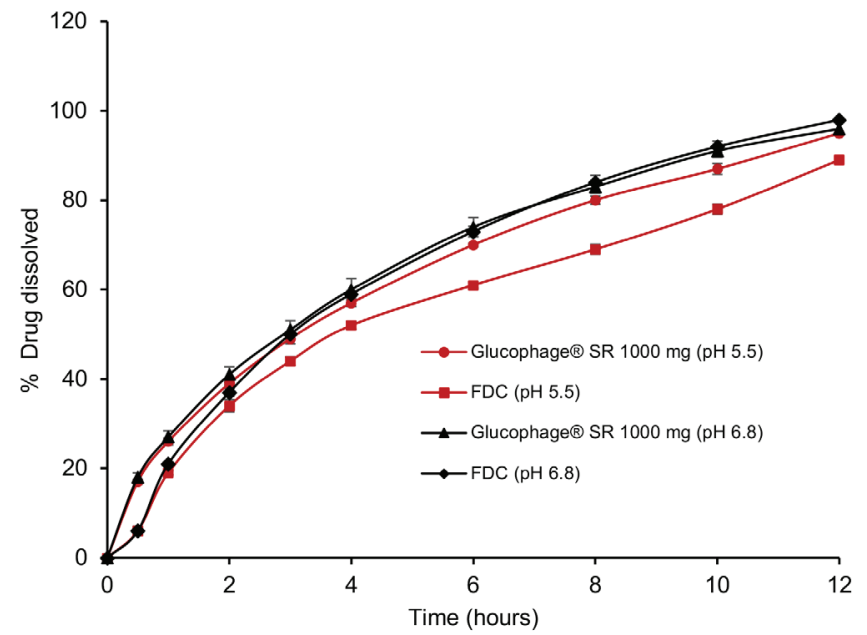

Figure 2. In vitro release of metformin $\mathrm{HCl}$ from $\mathrm{FDC}$ and Glucophage SR $1000 \mathrm{mg}$ at pH 6.8 and pH 5.5. Both the formulations contain $1000 \mathrm{mg}$ metformin $\mathrm{HCl}$ in the prolonged-release form

FDC: Fixed-dose combination

Table 2. Validation of the correlation model for sitagliptin

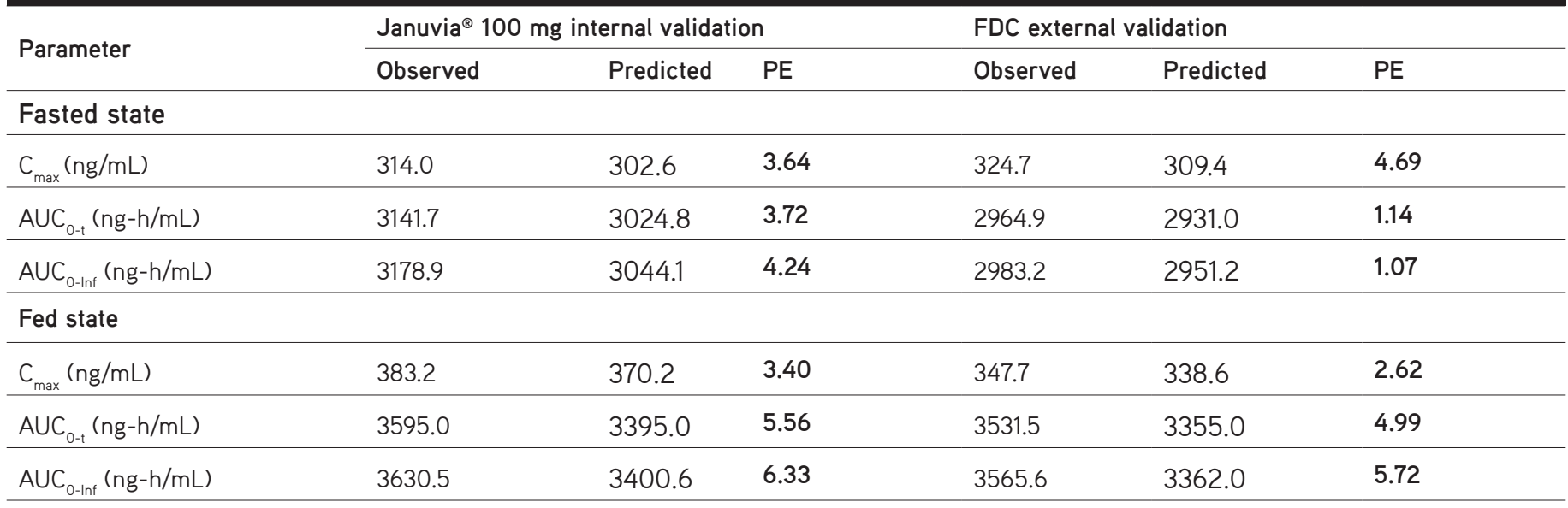

FDC: Fixed-dose combination, PE: Prediction error, $\mathrm{C}_{\mathrm{max}}$ : Peak drug concentration, $\mathrm{AUC}_{0-\mathrm{t}}$ : Area under the curve from time zero to time t, $A U \mathrm{C}_{0-\mathrm{ln}}:$ Area under the curve from time zero to infinity chosen in vitro conditions are appropriate and are mimicking the in vivo environment.

\section{Internal and external validation}

The internal and external predictability of sitagliptin for the $\mathrm{C}_{\text {max }}, \mathrm{AUC}_{\text {0-t, }}$ and $A \cup \mathrm{C}_{0-\text { Inf }}$ are presented in Table 2. The mean PE
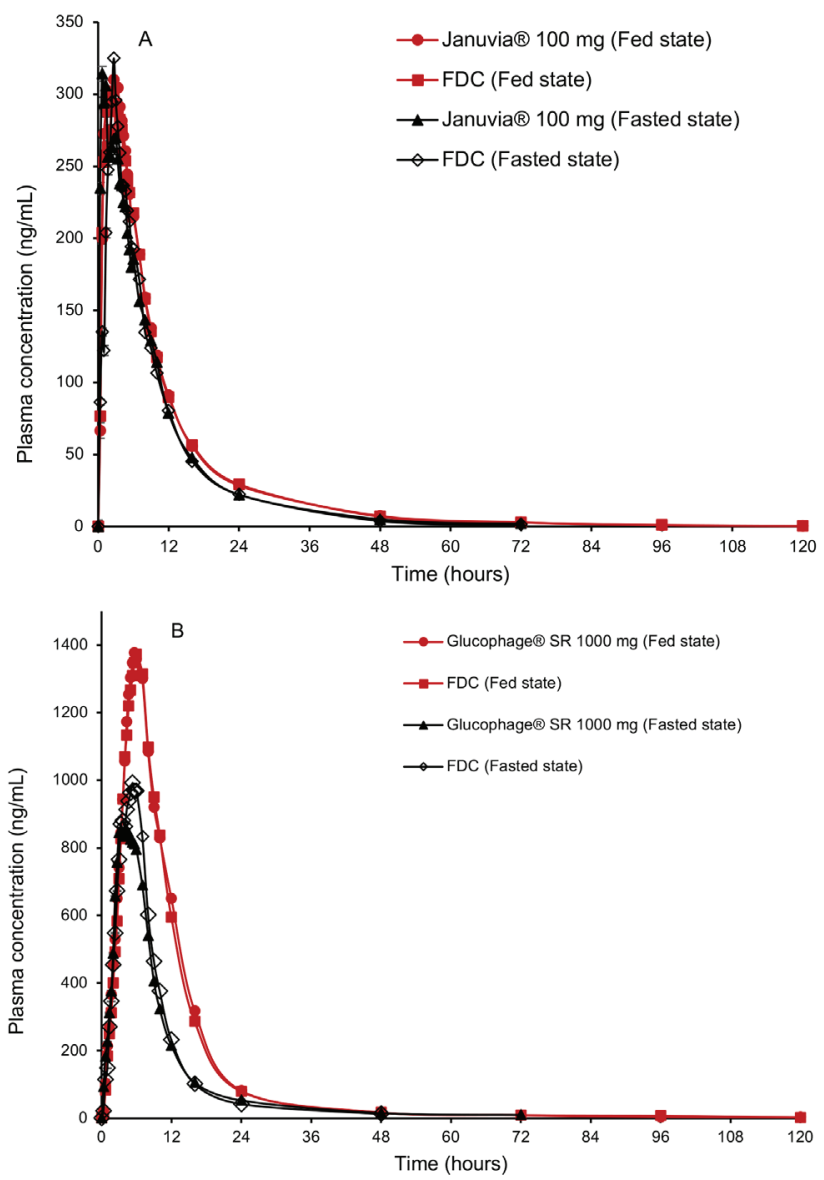

Figure 3. Mean plasma profile of sitagliptin in the fasted and fed states (A) and metformin in the fasted and fed states $(B)$ for the formulations used in the study

FDC: Fixed-dose combination 
values were below 10 for all the parameters and for both the formulations under fasted and fed conditions. The internal and external PE values were below $10 \%$ for metformin for all the principle pharmacokinetics (Table 3 ).
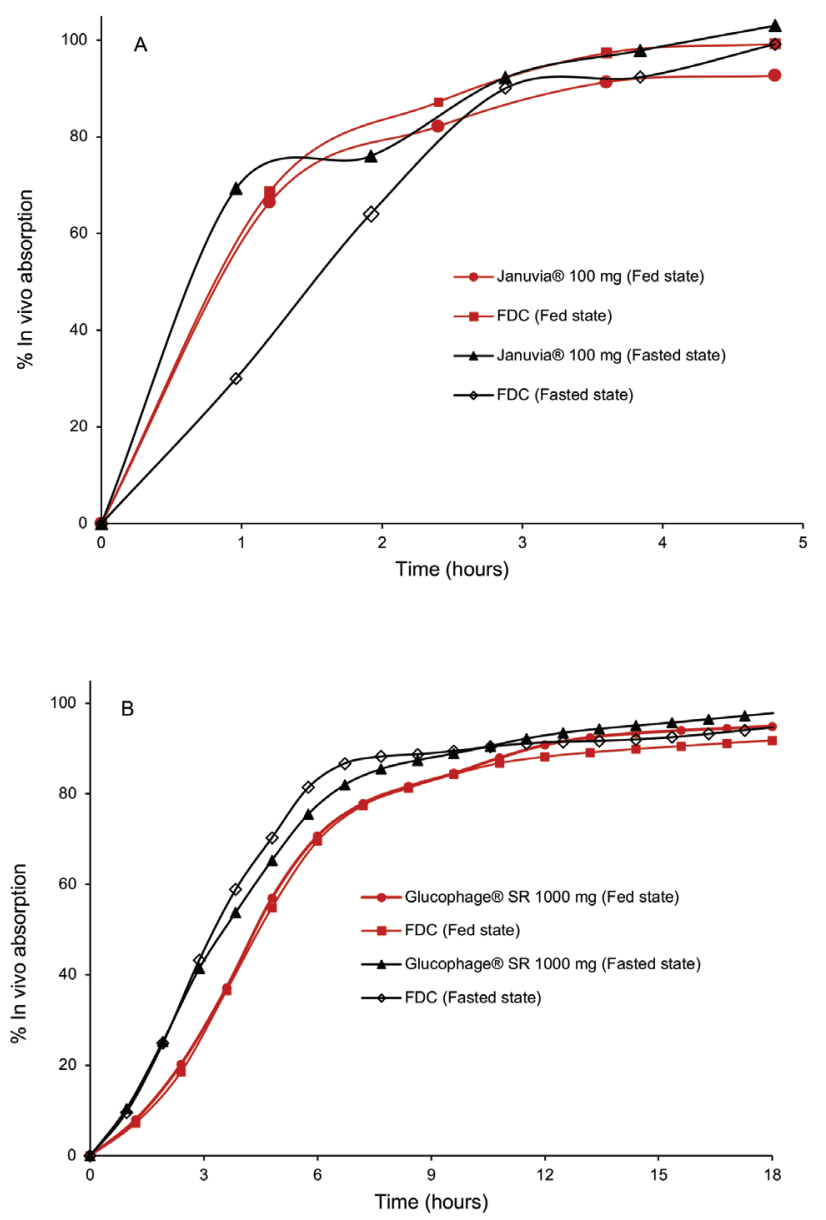

Figure 4. Mean in vivo absorption profiles for sitagliptin in the fasted state and the fed state $(A)$ and metformin in the fasted state and the fed state (B) for the reference and test formulations

FDC: Fixed-dose combination

\section{Safety and tolerability}

No serious adverse events (AEs) were reported in the bioequivalence study, and the intensity of reported AEs were deemed by the principal investigator as mild in severity. A total of five subjects showed eight AEs; among them, two subjects showed AEs for FDC and five showed AEs for the reference formulation. ${ }^{2}$ Despite the differences between salts of sitagliptin from reference (sitagliptin phosphate monohydrate) and those of the test formulation (FDC comprised of sitagliptin hydrochloride), the number of AEs with test formulation was "low" compared with the reference formulation under both fasted and fed conditions. The test and reference products were well tolerated, considering the AEs observed in the study. Therefore, sitagliptin hydrochloride can be deemed safe and is behaving in line with sitagliptin phosphate monohydrate from a safety perspective.

\section{DISCUSSION}

As per EMA guidelines, ${ }^{20}$ a validated IVIVC serves as a surrogate for in vivo performance. Internal and external validation of the IVIVC was performed in the current study. Therefore, the changes in the manufacturing process and some formulation modifications, including the product strength using the same formulation, can be justified using IVIVC, without the need for additional bioavailability/bioequivalence studies. Therefore, in present study, a correlation was established between in vitro drug release at $\mathrm{pH} 6.8$ (pre-prandial state) and pH 5.5 (postprandial state) versus the fraction of respective drug absorption in the fasted and fed states.

\section{Sitagliptin}

At $\mathrm{pH}$ 6.8, sitagliptin release was initially slow from the FDC compared with that of Januvia ${ }^{\circledR}$ and similar from 20 min onwards. The slow pattern of dissolution from the FDC could be due to the combination of immediate and prolonged-release formulations, where sitagliptin hydrochloride was present as an immediaterelease form along with the prolonged-release form, metformin $\mathrm{HCl}$, whereas Januvia ${ }^{\circledR}$ is an immediate-release tablet, and dissolution progresses as the tablets disintegrate. A similar

\section{Table 3. Validation of the correlation model for metformin}

\begin{tabular}{|c|c|c|c|c|c|c|}
\hline \multirow{2}{*}{ Parameter } & \multicolumn{3}{|c|}{ Glucophage $^{\circledR}$ SR 1000 mg internal validation } & \multicolumn{3}{|c|}{ FDC external validation } \\
\hline & Observed & Predicted & PE & Observed & Predicted & PE \\
\hline \multicolumn{7}{|l|}{ Fasted state } \\
\hline $\mathrm{C}_{\max }(\mathrm{ng} / \mathrm{mL})$ & 946.7 & 869.9 & 8.11 & 991.8 & 924.9 & 6.75 \\
\hline$A \cup C_{0-t}(n g-h / m L)$ & 8785.2 & 8720.9 & 0.73 & 8802.8 & 9093.4 & -3.30 \\
\hline$A \cup C_{0-\ln f}(n g-h / m L)$ & 9015.1 & 9057.6 & -0.47 & 9003.8 & 9438.9 & -4.83 \\
\hline \multicolumn{7}{|l|}{ Fed state } \\
\hline $\mathrm{C}_{\max }(\mathrm{ng} / \mathrm{mL})$ & 1255.9 & 1250.6 & 0.42 & 1375.68 & 1273.3 & 7.44 \\
\hline $\mathrm{AUC}_{0-\mathrm{t}}(\mathrm{ng}-\mathrm{h} / \mathrm{mL})$ & 15196.5 & 15549.6 & -2.32 & 15215.12 & 16380.5 & -7.66 \\
\hline$A \cup C_{0-\operatorname{lnf}}(n g-h / m L)$ & 16263.7 & 15815.8 & 2.75 & 15640.22 & 16653.2 & -6.48 \\
\hline
\end{tabular}

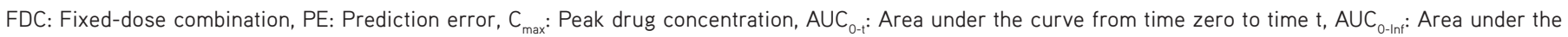
curve from time zero to infinity 
trend was also evident at $\mathrm{pH}$ 5.5. Despite the differences in dissolution, sitagliptin $\mathrm{HCl}$ from the FDC showed bioequivalence with Januvia ${ }^{\circledR}, 9$ indicating that both salts demonstrated similar in vivo behavior, which could be due to the high solubility and high bioavailability of sitagliptin., ${ }^{9,21}$ The physiological conditions of the Gl tract, such as peristaltic motility, ${ }^{22}$ appear to resemble the in vitro conditions, as evidenced from the similar in vivo performance. The in vitro difference during the initial phase of dissolution does not impact on the in vivo performance.

\section{Metformin}

The dissolution of FDC was slow at $0.5 \mathrm{~h}$ and followed by a similar release pattern in comparison with that of Glucophage ${ }^{\circledR}$ $1000 \mathrm{mg} \mathrm{SR}$ at $\mathrm{pH}$ 6.8. Similarly, the dissolution of FDC at $\mathrm{pH}$ 5.5 was slower by $5 \%-11 \%$ up to 10 hours. A similar trend was reflected in vivo, ${ }^{9}$ indicating the discrimination ability of the dissolution method to mimic the in vivo environment.

$$
\text { Rsq }=0.9518, \text { Intercept }=0.1825, \text { Slope }=3.005
$$

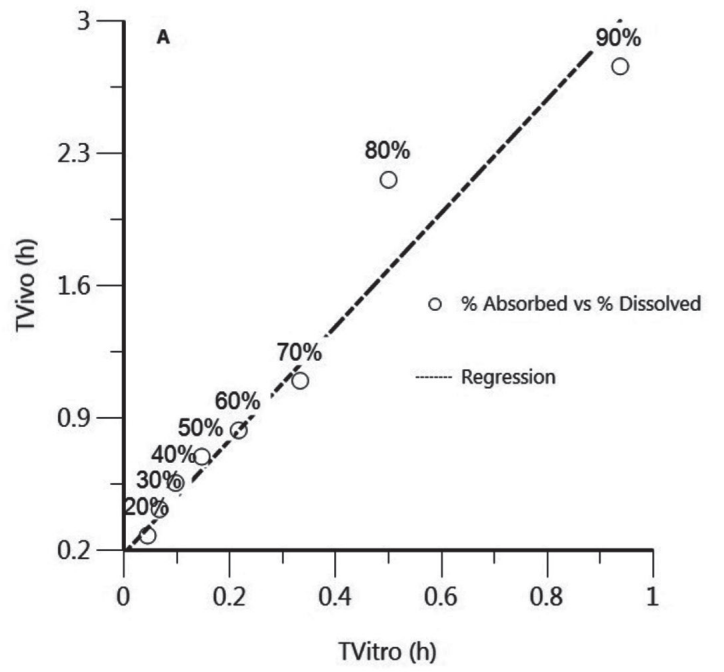

Rsq $=0.996$, Intercept $=0.1151$, Slope $=3.48$

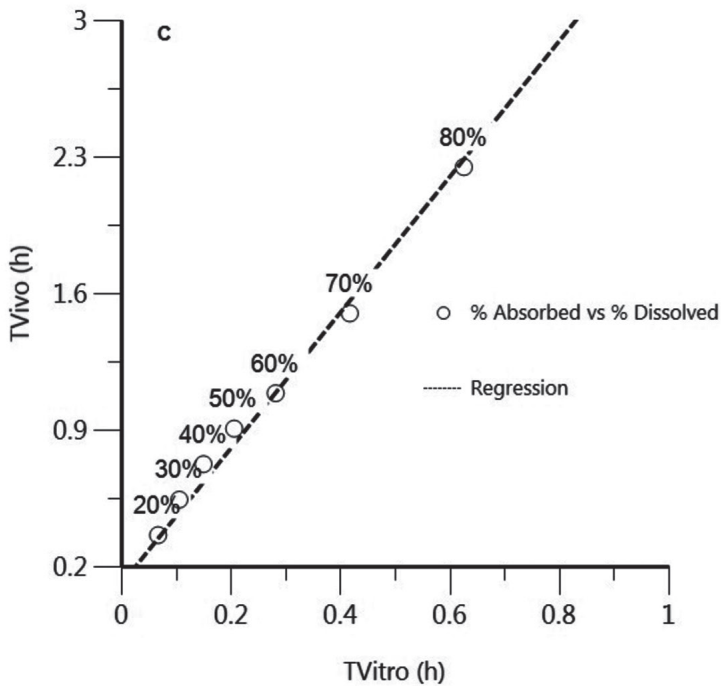

Furthermore, levy plots were constructed to establish a mathematical relationship linking $F_{\text {to }}$ to fraction of dissolved $\left(F_{d}\right)$ for both sitagliptin and metformin. To establish said relationship, the respective in vivo plasma concentration profiles for sitagliptin and metformin were deconvoluted into the $F_{a}$ and the $F_{d}$, which were derived from the respective in vitro dissolution profiles. The so-derived least-square regressions from the levy plots yielded essentially linear patterns (correlation coefficient >0.900) under both preprandial and postprandial conditions, demonstrating that the proposed in vitro biorelevant dissolutions can indeed explain the absorption of both sitagliptin and metformin satisfactorily. The constructed level " $A$ " levy plots demonstrated that the chosen in vitro conditions are appropriate and are mimicking the in vivo environment.

Further, the predictability of the developed IVIVC models were estimated in terms of PE values for the validation of the correlation models. An evaluation of internal and external
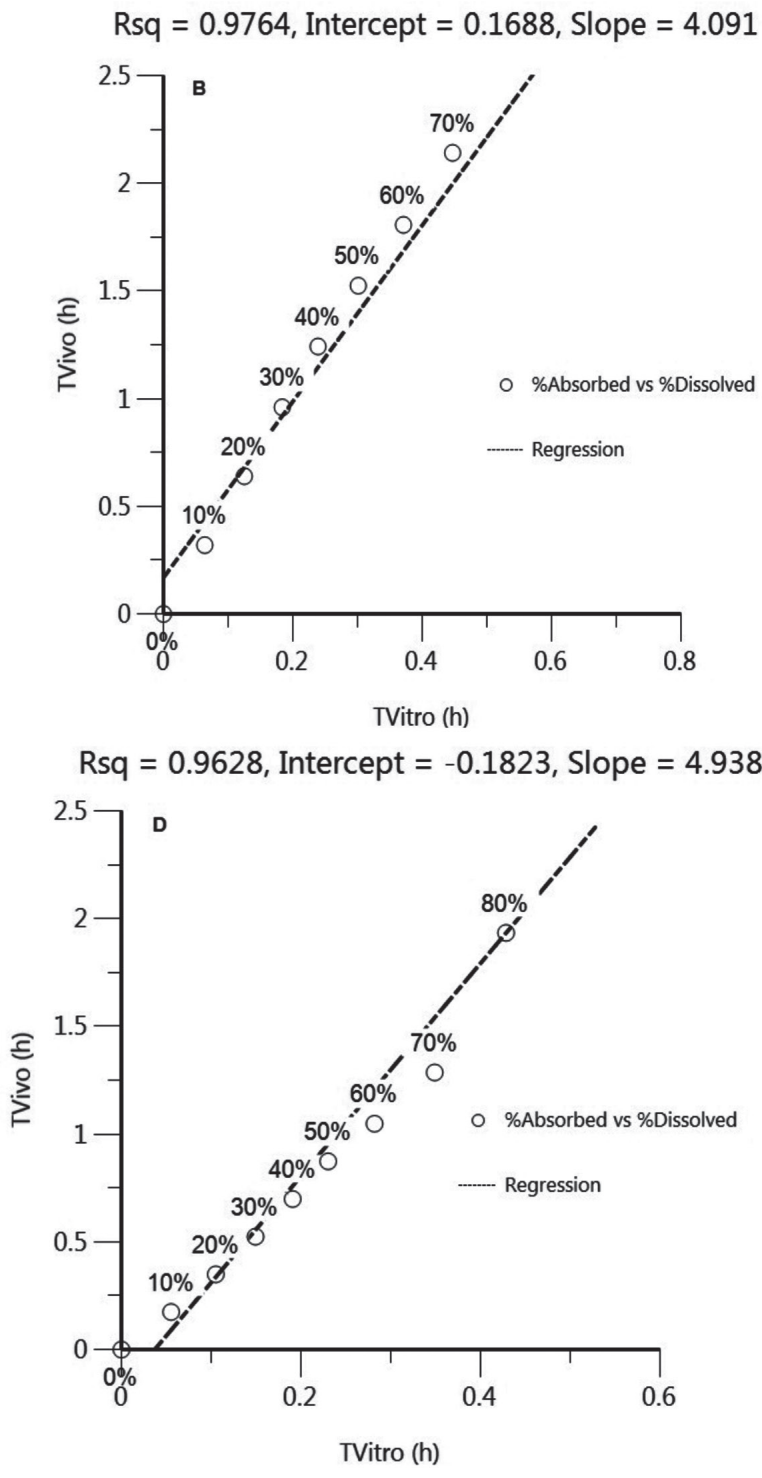

Figure 5. Levy plots for sitagliptin constructed using the fasted state data (A, B) and fed-state data (C, D). “A and C" denotes Januvia ${ }^{\circledR}$, and "B and D" denote the fixed-dose combination 
predictability for the pharmacokinetic parameters $\left(\mathrm{C}_{\text {max }}, \mathrm{AUC}_{0-\mathrm{t}^{\prime}}\right.$ and $A \cup C_{0-\operatorname{lnf}}$ ) was below $10 \%$ and demonstrated the predefined internal and external validation criteria. ${ }^{19}$ Overall, the attained IVIVC models yielded predicted $\mathrm{C}_{\text {max }}$ and AUC parameters below $10 \%$ of the observed values for both internal and external validations in both the fasted and the fed state. A proven IVIVC and a discriminatory in vitro method can serve as a surrogate for in vivo characterization and be used to select suitable formulations for in vivo studies. ${ }^{23}$ The bioequivalence results also substantiated the validity of the developed IVIVC models for both sitagliptin and metformin; hence, the correlation models can be deemed to be robust and can therefore be considered for predicting in vivo performance.

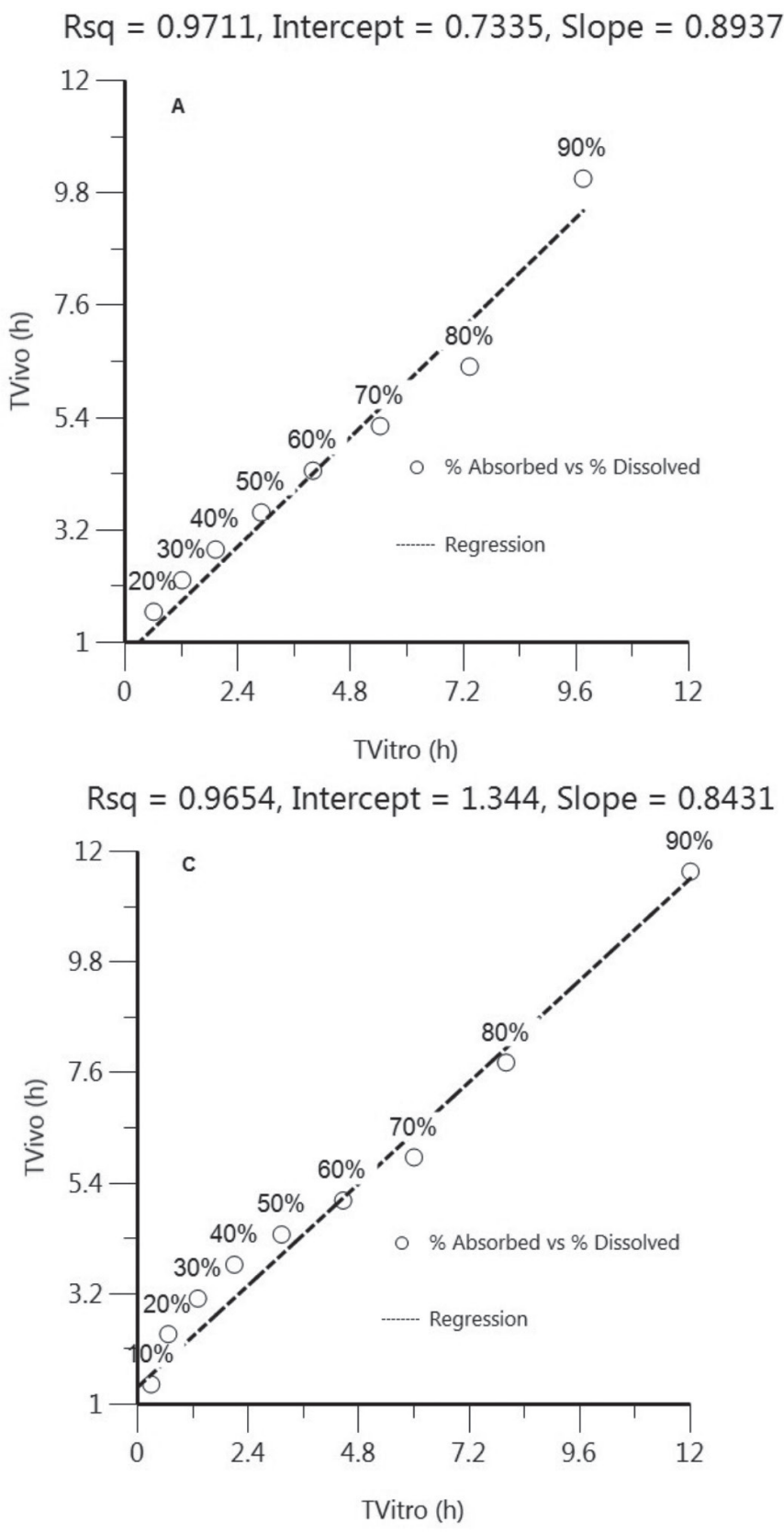

The bioequivalence results reveal that FDC is well tolerated and safe for use in humans. From an in vivo behavior and safety perspective, the FDC product consisting of sitagliptin $\mathrm{HCl}$ and prolonged-release metformin $\mathrm{HCl}$ showed more or less similar in vivo behavior in comparison with the individual reference formulations. Therefore, FDC can enhance patient compliance, as it minimizes the consumption of individual products.

\section{CONCLUSION}

A robust IVIVC (level A) that meets the validation criteria for both internal and external predictability was established for sitagliptin and metformin prolonged-release formulations. Although the sitagliptin salt form is different in the test and
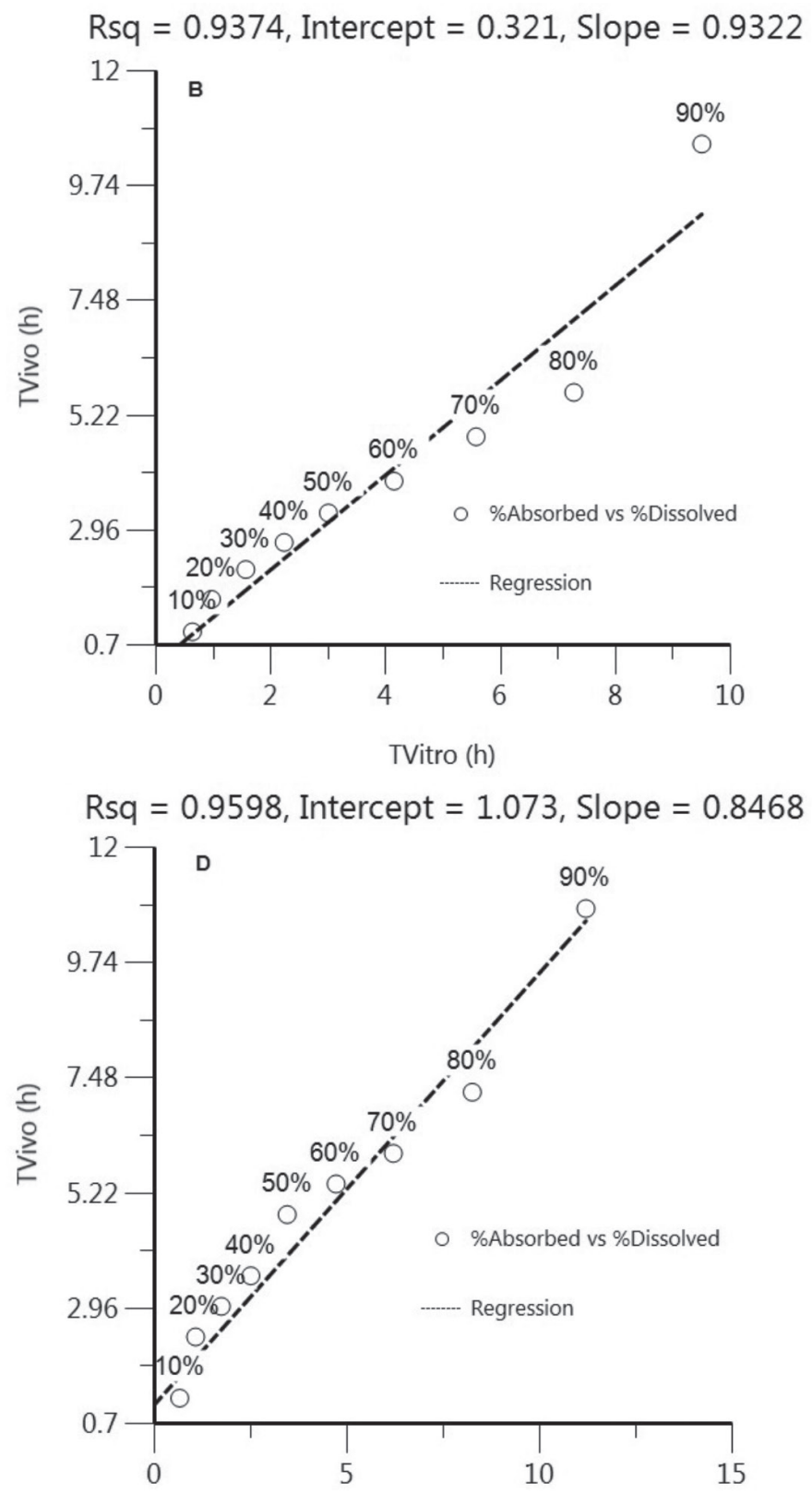

TVitro (h)

Figure 6. Levy plots for metformin constructed using the fasted state data (A, B) and fed-state data (C, D). “A and C" denotes Glucophage ${ }^{\circledR}$ SR 1000 mg, and "B and D" denote the fixed-dose combination 
reference products (FDC contains sitagliptin hydrochloride, and Januvia ${ }^{\circledR}$ contains sitagliptin phosphate monohydrate), the developed IVIVC model exhibited good predictability. The correlation models can be used to predict formulations containing immediate-release sitagliptin salts (as $\mathrm{HCl}$ or phosphate monohydrate as the salts) and prolonged-release metformin $\mathrm{HCl}$. The IVIVC can also be used as a surrogate for bioequivalence studies in the case of future formulation changes that are covered by the IVIVC release rates. The FDC comprising sitagliptin $\mathrm{HCl}$ and Metformin $\mathrm{HCl}$ was well tolerated in human volunteers, and the rate of AEs was similar to that of reference products; hence, FDC can be deemed safe for use in human subjects.

Conflicts of interest: No conflict of interest was declared by the authors. The authors alone are responsible for the content and writing of the paper.

\section{REFERENCES}

1. Pathak R, Bridgeman MB. Dipeptidyl Peptidase-4 (DPP-4) Inhibitors in the management of diabetes. Pharm Therap. 2010;35:509-513.

2. Shah Z, Kampfrath T, Deiuliis JA, Zhong J, Pineda C, Ying Z, Xu X, Lu B, Moffatt-Bruce S, Durairaj R, Sun Q, Mihai G, Maiseyeu A, Rajagopalan $\mathrm{S}$. Long-term dipeptidyl-peptidase 4 inhibition reduces atherosclerosis and inflammation via effects on monocyte recruitment and chemotaxis. Circulation. 2011;124:2338-2349.

3. American Diabetes Association. Standards of medical care in diabetes-2014. Diabetes Care. 2014;37:S14-S80.

4. Pernicova I, Korbonits M. Metformin--mode of action and clinical implications for diabetes and cancer. Nat Rev Endocrinol. 2014;10:143156.

5. Rena G, Hardie DG, Pearson ER. The mechanisms of action of metformin. Diabetologia. 2017;60:1577-1585

6. FDA, Janumet XR, SBOA, Application no: 202270: Available from https://www. accessdata.fda.gov/drugsatfda_docs/nda/2012/2022700rig1s000ClinPharmR. pdf Accessed February 062020.

7. Cheng CL, Yu LX, Lee HL, Yang CY, Lue CS, Chou CH. Biowaiver extension potential to BCS Class III high solubility-low permeability drugs: bridging evidence for metformin immediate-release tablet. Eur J Pharm Sci. 2004:22:297-304.

8. Shahid S, Delowar H. Fixed dose combination and disease management. Int Res J Pharm. 2012;3:17-21.

9. Prathap VR, Vadla HC, Rallabandi BC, Gannu R. Bioequivalence, safety and tolerability of sitagliptin $100 \mathrm{mg}$ and metformin hydrochloride $1000 \mathrm{mg}$ prolonged-release tablets in healthy adult volunteers. Am J Pharmacol Ther. 2018;2:001-006.

10. EMA. European Medicines Agency. Guidance on the Investigation of Bioequivalence. Available from: https://www.ema.europa. eu/en/documents/scientific-guideline/guideline-investigationbioequivalence-rev1_en.pdf. February 04 2020, 2010.
11. Dressman JB, Berardi RR, Dermentzoglou LC, Russel TL, Schmaltz SP, Barnett JL, Jarvenpaa KM. Upper gastrointestinal (Gl) pH in young, healthy men and women. Pharm Res. 1990;7:756-761.

12. Sandra K, Martin W, Jennifer D and Erika S. Development of Dissolution Tests on the basis of Gastrointestinal physiology from Pharmaceutical dissolution testing. In: Jennifer D, Johannes K eds. Taylor \& Francis Group;2005:193-227.

13. Lindahl A, Ungell AL, Knutson L, Lennernas $H$. Characterization of fluids from the stomach and proximal jejunum in men and women. Pharm Res. 1997;14:497-502.

14. Malleswararao CS, Suryanarayana MV, Mukkanti K. Simultaneous determination of sitagliptin phosphate monohydrate and metformin hydrochloride in tablets by a validated UPLC method. Sci Pharm. 2012;80:139-152.

15. Guideline on the investigation of bioequivalence. European Medicine Agency Guidelines. 2010.

16. $\mathrm{ICH}$ harmonized guidelines. Integrated addendum to $\mathrm{ICH}$ E6 (R1): guideline For Good Clinical Practice E6 (R2). 2016.

17. Bioanalytical Method Validation. Guidance for Industry. U.S. Department of Health and Human Services Food and Drug Administration. Retrieved from https://www.fda.gov/media/70858/download Available from: May2018.

18. Guideline on bioanalytical method validation. EMEA/CHMP/ EWP/192217/2009 Rev. 1 Corr. $2^{* *}$ Committee for Medicinal Products for Human Use (CHMP) dated 21 July 2011. Retrieved from https://www.ema. europa.eu/en/documents/scientific-guideline/guideline-bioanalyticalmethod-validation_en.pdf

19. FDA. Guidance for Industry. Extended release oral dosage forms: development, evaluation, and application of in vitro/in vivo correlations. US Department of Health and Human Services, Food and Drug Administration, Center for Drug Evaluation and Research (CDER). Available from: https:/www.fda.gov/downloads/drugs/guidances/ ucm070239.pdf Accessed:February 042020.

20. EMA. European Medicines Agency. Guideline on the pharmacokinetic and clinical evaluation of modified release dosage forms (EMA/CPMP/ EWP/280/96 Corr1). Available from https://www.ema.europa.eu/en/ documents/scientific-guideline/guideline-pharmacokinetic-clinicalevaluation-modified-release-dosage-forms_en.pdf. Accessed February 06 2020. 2015.

21. Tsume $Y$, Mudie DM, Langguth $P$, Amidon GE, Amidon GL. The Biopharmaceutics Classification System: subclasses for in vivo predictive dissolution (IPD) methodology and IVIVC. Eur J Pharmaceut Sci. 2014;57:152-163.

22. Bonlokke L, Hovgaard L, Kristensen HG, Knutson L, Lindahl A, Lennernas $\mathrm{H}$. A comparison between direct determination of in vivo dissolution and the deconvolution technique in humans. Eur $\mathrm{J}$ Pharmaceut Sci. 1999;8:19-27.

23. Cardot JM, Beyssac E, Alric M. In vitro-in vivo correlation: Importance of dissolution in IVIVC. Disso Tech. 2007:14:15-19. 